\title{
Pseudomonas SP. in uninspected raw goat's milk in Rio de Janeiro, Brazil
}

\author{
Gustavo Luis de Paiva Anciens RAMOS ${ }^{1,2}$, Janaína dos Santos NASCIMENTO ${ }^{1 \star ~(D) ~}$
}

\begin{abstract}
Although quite controversial from the point of view of food safety, a considerable number of people across different age and socioeconomic groups consume raw goat's milk. Even if refrigerated after milking, raw goat's milk may still be susceptible to the lipolytic and proteolytic actions of psychrotrophic microorganisms, such as Pseudomonas. In this study, Pseudomonas sp. from 21 refrigerated raw goat's milk samples were characterized. All samples were freely commercialized, without any type of inspection, by small producers and markets from different regions of Rio de Janeiro, Brazil. A total of 136 isolates were identified, most of which belonged to the species, $P$. putida, P. koreensis, P. monteilii, and P. fluorescens. The production of protease and lipase varied according to the incubation temperature. We found that $91.4 \%$ of the Pseudomonas isolates were susceptible to all antibiotics tested. None of the isolates exhibited a multidrug-resistance phenotype. None of the raw goat's milk samples contained detectable antibiotic residues, which may explain the very low frequency of resistant bacteria. Although Pseudomonas is not considered a typical food-related pathogen, its presence indicate that the determination of microbiological standards for raw goat's milk and greater control of the commercialization of this product, are necessary.
\end{abstract}

Keywords: refrigerated raw goat's milk; Pseudomonas spp.; antibiotic susceptibility; proteolytic and lipolytic activity; biofilm production; antibiotic resistance.

Practical Application: This work relates the presence of Pseudomonas sp. and their degradative enzymes in raw goat's milk.

\section{Introduction}

Several studies have shown that, in comparison to cow's milk, goat's milk has improved digestibility, greater therapeutic and nutritional value, and reduces the risk of developing allergies (Lai et al., 2016; Hodgkinson et al., 2017).

Despite having lower consumer acceptance than the cow's milk, several goat milk products have been developed over the last decade, such as probiotics, cheese, yogurt and fermented milk. Goat milk production has also been increasing year after year, and currently reaches about 13 million tons annually (Beltrán et al., 2017; Mituniewicz-Małek et al., 2019; Ranadheera et al., 2019).

However, goat's milk, as well as milk from other animals, can be easily damaged by micro-organisms. Microbiological contamination of raw milk can occur during milking, either by commensal microbiota or by those that cause diseases, such as mastitis. However, it can also occur during processing, handling, distribution, or storage (Oliver et al., 2009; Alegbeleye et al., 2018).

In Brazil, to ensure food safety, is recommended that only pasteurized milk be used for human consumption. However, in some regions of the State of Rio de Janeiro, it is common to commercialize and consume raw goat's milk, due to the fact that consumers believe that this food, when consumed "in natura", is healthier than milk that has undergone any type of processing.

Fresh milk taken from a healthy ruminant generally contains a low bacterial load of less than $10^{3} \mathrm{cfu} / \mathrm{mL}$. However, a significant increase in bacterial load may occur when the milk is stored for a long period of time at room temperature (Lingathurai et al., 2009). Therefore, the refrigeration of goat's milk should be a practice adopted to prevent the growth of non-psychrotrophic microorganisms (Lai et al., 2016).

Pseudomonas sp., however, constitute the dominant psychrotrophic bacteria isolated from raw refrigerated milk and, in the dairy industry, they are the main agents associated with the deterioration of these foods (Corrêa et al., 2011). Also, the formation of different types of volatile organic compounds during storage, especially by this bacterial genus, may alter the final quality of the product (Decimo et al., 2018).

The objective of this work was to characterize the Pseudomonas sp. in raw goat's milk marketed in the State of Rio de Janeiro and to investigate the possible relationship between the presence of antibiotic residues in milk samples and the resistance profile of the isolated microorganisms.

\section{Material and methods}

\subsection{Raw goat's milk samples}

The 21 samples of refrigerated raw goat's milk used in this study were purchased directly from small producers or commercial establishments in different regions of the State of Rio de Janeiro, Brazil, and transported under refrigeration to the Instituto Federal de Educação, Ciência e Tecnologia do Rio de Janeiro (IFRJ) Microbiology Laboratory within a maximum

${ }^{1}$ Laboratório de Microbiologia, Instituto Federal de Educação, Ciência e Tecnologia do Rio de Janeiro - IFRJ, Rio de Janeiro, RJ, Brasil

${ }^{2}$ Laboratório de Higiene e Microbiologia de Alimentos, Faculdade de Farmácia, Universidade Federal Fluminense (UFF), Niterói, RJ, Brasil

${ }^{*}$ Corresponding author: janaina.nascimento@ifrj.edu.br 
of 4 hours. None of the samples purchased from commercial establishments contained a label or a seal of sanitary surveillance food inspection by government entities.

\subsection{Peroxidase test}

The detection of peroxidase activity in the raw milk samples was performed by colorimetric test strips according to the manufacturing instructions (Cap-Lab, São Paulo, Brazil). One strip was immersed in each milk sample for $10 \mathrm{~s}$ and the excess shaken off gently. Peroxidase activity is indicated by the formation of a reddish brown color.

\subsection{Isolation and bacterial identification}

Each milk sample was diluted in $0.1 \%(\mathrm{w} / \mathrm{v})$ peptone water (BIOCEN, São Paulo, Brazil). The diluted samples were inoculated onto violet red bile glucose (VRBG) agar (Kasvi, São Paulo, Brazil), which was employed primarily since the initial purpose of the work was to isolate bacteria from the Enterobacteriacaeae family, not $P$ seudomomas. The plates were incubated at $37^{\circ} \mathrm{C}$ for $18-24 \mathrm{~h}$ and bacterial colonies were quantified and expressed in $\mathrm{cfu} \mathrm{mL}^{-1}$. To reduce the possibility that the selected isolates belonged to the same strain, several colonies with different morphologies on VRBG agar were collected and inoculated onto Tryptone Soy Agar (Casoy, BIOCEN) for mass gain. The isolates were then stored frozen in cryotubes with Casoy broth (Merck, São Paulo, Brazil) and 40\% (v/v) glycerol (Merck). Isolates were identified by MALDI-TOF mass spectrometry (Microflex LT; Bruker, Billerica, MA, USA). Each isolate was inoculated in Casoy agar at $37^{\circ} \mathrm{C}$ for $24 \mathrm{~h}$ and then transferred to a microplate (96 MSP, Bruker, Billerica, USA) with the aid of a sterile toothpick. The bacterial mass was lysed with $70 \%$ formic acid (Sigma-Aldrich) and a $1-\mu \mathrm{L}$ aliquot of matrix solution (alpha-ciano-4-hidroxi-cinamic acid diluted in 50\%(v/v) acetonitrile [Sigma-Aldrich] and 2.5\% (v/v) trifluoracetic acid [Sigma-Aldrich]) was added to each sample. The spectra of each sample were generated by the MALDI-TOF equipment and then were analyzed by the MALDI Biotyper 3.1 (Bruker) program, using the standard configuration for bacteria identification, by which the spectrum of the sample is compared to the references in the database.

\subsection{Qualitative evaluation of biofilm production}

The isolates were inoculated onto the surface of Congo red agar (CRA), formulated from $15 \mathrm{~g} / \mathrm{L}$ nutrient agar (Merck), $37 \mathrm{~g} / \mathrm{L}$ sucrose (Pro Analysi, São Paulo, Brazil) and $0.8 \mathrm{~g} / \mathrm{L}$ Congo red (VETEC, Rio de Janeiro, Brazil), as indicated by Freeman et al. (1989). Biofilm production was evaluated after incubation at $7{ }^{\circ} \mathrm{C}$ and $28^{\circ} \mathrm{C}$ for up to 10 days. Using this method, colonies that produce a biofilm are black and those that do not are colorless or reddish.

\subsection{Evaluation of proteolytic activity}

Isolates were inoculated onto skim milk agar [1\% skim milk powder (Molico ${ }^{\circ}$, Nestlé Brasil Ltda, São Paulo, SP, Brazil), 0.5\% yeast extract (BD Biosciences, San Jose, CA, USA), 1.5\% agar-agar (Merck)]. The inoculated plates were incubated at $7^{\circ} \mathrm{C}$ and $28^{\circ} \mathrm{C}$ for up to 10 days (Hantsis-Zacharov \& Halpern, 2007). Casein hydrolysis by proteases produced by the microorganisms was observed as halos around the colonies.

\subsection{Evaluation of lipolytic activity}

Isolates were inoculated onto plates containing Spirit Blue agar (Atlas, 2010), with modifications, consisting of $1 \%(\mathrm{p} / \mathrm{v})$ peptone (Himedia, Mumbai, India), $0.5 \%(\mathrm{w} / \mathrm{v})$ yeast extract (BD Biosciences, San Jose, CA, USA), 2\% (w/v) agar, and 3\% $(\mathrm{v} / \mathrm{v})$ lipoidal emulsion $(20 \%$ [v/v] of olive oil [Borges, Tàrrega, Spain], 0.2\% (v/v) Tween 80 [Proquimios, Rio de Janeiro, Brazil]). Lipoidal emulsion was added after autoclaving and cooling to $55^{\circ} \mathrm{C}$. Plates were incubated at $7^{\circ} \mathrm{C}$ and $28^{\circ} \mathrm{C}$ for up to 10 days and the presence of halos around the bacterial growth was observed, indicating lipid degradation through the production of lipases by the isolated microorganisms.

\subsection{Antibiotic resistance profile}

The disc diffusion method was used to determine the antibiotic resistance profile, following the methodology described by the Clinical and Laboratory Standards Institute (2018). The following antibiotics (Sensifar, São Paulo, Brazil) were employed: meropenem $(10 \mu \mathrm{g})$, imipenem $(10 \mu \mathrm{g})$, ceftazidime $(30 \mu \mathrm{g})$, cefepime (30 $\mu \mathrm{g})$, aztreonam $(30 \mu \mathrm{g})$, ciprofloxacin $(5 \mu \mathrm{g})$, levofloxacin $(5 \mu \mathrm{g})$, gentamicin $(10 \mu \mathrm{g})$, tobramycin $(10 \mu \mathrm{g})$, piperacyllin/tazobactam $(100 / 10 \mu \mathrm{g})$. Microorganisms were classified as multiresistant if they were resistant to at least one antibiotic from at least three different classes (Magiorakos et al., 2012).

\subsection{Delvotest $T^{\circledR}$ microbial test}

Qualitative analysis of antibiotic residues in milk was performed using the Delvotest $\mathrm{T}^{\oplus}$ (DSM, Heerlen, Netherlands) assay, according to the manufacturer's instructions. As positive controls, ampicillin and tetracycline were added to raw goat's milk samples at the maximum residue limit (4 and $100 \mu \mathrm{g} . \mathrm{L}^{-1}$, respectively), according to the Codex Alimentarius Commission (Food and Agriculture Organization, 2018).

\section{Results and discussion}

In view of its nutritional value and its other functional properties, goat's milk can be used as a matrix for new products, giving rise to a market with great potential for exploitation, with innovative derivatives and high added value. There is, however, a growing demand for high-quality milk products with a long shelf-life, thus milk undergoing the pasteurization process has advantages over raw milk, which may be more susceptible to changes in its organoleptic properties due to the growth of micro-organisms.

Initially, the objective of this study was to isolate and characterize members of the Enterobacteriaceae family present in raw goat's milk. However, even when using VRBG, a culture medium favoring the growth of enterobacteria, different species of Pseudomonas sp. were found. Besides Pseudomonas, this medium allows the growth of other bacteria not belonging to the Enterobacteriaceae family, as described by Cho et al. 
(2018), whose isolates of Acinetobacter sp. used in their work from samples of milk powder were also recovered from VRBG. A Japanese study also emphasizes the importance of considering the growth of strains of the genus Pseudomonas when researching Enterobacteriaceae using VRBG agar, as recommended by the International Organization for Standardization (2004), especially in raw and pasteurized milk samples. Depending on the type of sample, incubation temperature, and species present, different growth rates of Pseudomonas sp., including $P$. aeruginosa, can be obtained (Sato et al., 2014).

In this study, of 222 Gram-negative bacilli isolated and identified from 21 samples of raw goat's milk using VRBG agar, 136 (61.3\%) belonged to the genus Pseudomonas. All samples except six (\#3,5,10,11,12, and 21) showed the presence of bacteria of this genus. The number of isolates selected per sample is shown in Table 1.

Generally, overheating fraud is performed to mask poor microbiological quality of the raw milk. In all the samples of goat milk used in this work, the peroxidase enzyme was detected, indicating that the samples had not been heated at temperatures higher than $80^{\circ} \mathrm{C}$, since for 20 seconds at this temperature the enzyme is inactivated (Blel et al., 2002). However, three of the samples (\#3,10, and 11) showed counts in VRBG agar below $1,0 \times 10 \mathrm{cfu} / \mathrm{ml}^{-1}$. This result was not expected because this culture medium is primarily indicated for the quantification of bacteria of the family Enterobacteriaceae, which are very common in samples of raw milk. Thus, aerobic mesophilic bacteria were quantified on plate count agar (International Organization for Standardization, 2013) and these three samples had counts between $7.2 \times 10^{2}$ and $1.6 \times 10^{3} \mathrm{cfu} \cdot \mathrm{mL}^{-1}$. These results reduced the suspicion that the samples had been adulterated by the addition of some chemical to eliminate the microbial load.

Table 2 shows the identification of the 136 isolates of Pseudomonas. Most of them $(16.9 \% ; \mathrm{n}=23)$ belong to the species $P$. koreensis. We did not detect $P$. aeruginosa in any of the raw goat's milk samples analyzed. This result was also observed by Ribeiro Júnior et al. (2018b) in raw goat's milk samples from the state of Paraná, Brazil. They identified 60 isolates of Pseudomonas spp., most of which belonged to the species, $P$. azotoformans, $P$. koreensis, $P$. gessardii, $P$. monteilii, and $P$. lurida. In the same study, the authors analyzed raw bovine milk and found that $P$. aeruginosa was the most commonly isolated species (Ribeiro Júnior et al., 2018b). They also suggested that the diversity of Pseudomonas species observed in goat's milk may be related to the lack of hygienic practices in the milking of goats, thus allowing a wide variety of microorganisms to come in contact with the milk.

At $28{ }^{\circ} \mathrm{C}$, the number of isolates producing proteases and lipases was $80(59 \%)$ and $65(48 \%)$, respectively. However, a lower number of isolates were also able to produce these enzymes at $7{ }^{\circ} \mathrm{C}$ (Table 2), as also observed in other studies involving Pseudomonas sp. isolated from raw goat milk (Scatamburlo et al., 2015, Ribeiro Júnior et al., 2018a, b). Among the 13 isolates of P. fluorescens, proteolytic and lipolytic activities were detected, respectively, in $11(84.6 \%)$ and $9(69.2 \%)$ isolates, both at $7{ }^{\circ} \mathrm{C}$ and $28^{\circ} \mathrm{C}$, which has also been reported by other authors as a characteristic frequently associated with this psychrotrophic species (Baglinière et al., 2012; Martins et al., 2015). According

Table 1. Characteristics of raw goat's milk samples used in this study and the number of Pseudomonas sp. isolates obtained from each sample.

\begin{tabular}{|c|c|c|c|c|c|}
\hline Sample & Origin & $\begin{array}{c}\text { Presence of } \\
\text { antimicrobial } \\
\text { residues }\end{array}$ & $\begin{array}{l}\text { Aerobic mesophilic } \\
\left.\text { Count (cfu. } \mathrm{ml}^{-1}\right)\end{array}$ & $\begin{array}{l}\text { VRBG Agar count } \\
\left(\text { cfu.ml }{ }^{-1}\right)\end{array}$ & $\begin{array}{c}\text { Number of } \\
\text { Pseudomonas } \\
\text { isolates }\end{array}$ \\
\hline 1 & Centro, Santo Antônio de Pádua (CE) & no & $1,8 \times 10^{7}$ & $4,9 \times 10^{3}$ & 17 \\
\hline 2 & Taquara, Jacarepaguá, Rio de Janeiro City (CE) & no & $1,5 \times 10^{3}$ & $1,0 \times 10$ & 2 \\
\hline 3 & Taquara, Jacarepaguá, Rio de Janeiro City (CE) & no & $8,0 \times 10^{2}$ & $<1,0 \times 10$ & 0 \\
\hline 4 & Jardim da Aldeia, Itaocara (SP) & no & $1,6 \times 10^{8}$ & $1,8 \times 10^{6}$ & 1 \\
\hline 5 & Porto das Barcas, Aperibé (SP) & no & $2,0 \times 10^{7}$ & $6,7 \times 10^{5}$ & 0 \\
\hline 6 & Recanto das Palmeiras, Cordeiro (SP) & no & $1,0 \times 10^{4}$ & $3,0 \times 10^{2}$ & 3 \\
\hline 7 & Vargem Pequena, Rio de Janeiro City (CE) & no & $2,1 \times 10^{5}$ & $3,6 \times 10^{3}$ & 8 \\
\hline 8 & Vargem Pequena, Rio de Janeiro City (CE) & no & $4,0 \times 10^{5}$ & $2,2 \times 10^{3}$ & 6 \\
\hline 9 & Vargem Pequena, Rio de Janeiro City (CE) & no & $>1,0 \times 10^{4}$ & $2,3 \times 10^{3}$ & 5 \\
\hline 10 & Taquara, Jacarepaguá, Rio de Janeiro City (CE) & no & $1,6 \times 10^{3}$ & $<1,0 \times 10$ & 0 \\
\hline 11 & Taquara, Jacarepaguá, Rio de Janeiro City (CE) & no & $7,2 \times 10^{2}$ & $<1,0 \times 10$ & 0 \\
\hline 12 & Jardim da Aldeia, Itaocara (SP) & no & $1,5 \times 10^{9}$ & $2,8 \times 10^{6}$ & 0 \\
\hline 13 & Jardim da Aldeia, Itaocara (SP) & no & $8,8 \times 10^{7}$ & $1,1 \times 10^{4}$ & 20 \\
\hline 14 & Cidade Nova, Santo Antônio de Pádua (SP) & no & $6,8 \times 10^{7}$ & $9,5 \times 10^{3}$ & 20 \\
\hline 15 & Cidade Nova, Santo Antônio de Pádua (SP) & no & $3,0 \times 10^{4}$ & $9,0 \times 10^{2}$ & 6 \\
\hline 16 & Recanto das Palmeiras, Cordeiro (SP) & no & $>1,0 \times 10^{5}$ & $2,2 \times 10^{4}$ & 12 \\
\hline 17 & Recanto das Palmeiras, Cordeiro (SP) & no & $1,0 \times 10^{4}$ & $4,8 \times 10^{2}$ & 4 \\
\hline 18 & Recanto das Palmeiras, Cordeiro (SP) & no & $3,0 \times 10^{4}$ & $1,2 \times 10^{3}$ & 12 \\
\hline 19 & Centro, Santo Antônio de Pádua (CE) & no & $>1,0 \times 10^{4}$ & $1,4 \times 10^{3}$ & 8 \\
\hline 20 & Centro, Santo Antônio de Pádua (CE) & no & $9,6 \times 10^{4}$ & $6,0 \times 10^{2}$ & 12 \\
\hline 21 & Porto das Barcas / Aperibé (SP) & no & $1,0 \times 10^{4}$ & $1,0 \times 10^{2}$ & 0 \\
\hline
\end{tabular}

CE: samples acquired from small commercial establishments; SP: samples acquired directly from small producers. 
Table 2. Characteristics of the Pseudomonas sp. isolates obtained from samples of raw goat's milk.

\begin{tabular}{|c|c|c|c|c|c|c|c|}
\hline \multirow{2}{*}{ Pseudomonas isolates } & \multicolumn{2}{|c|}{ Proteolytic activity $^{\mathrm{a}}$} & \multicolumn{2}{|c|}{ Lipolytic activity $^{\mathrm{a}}$} & \multicolumn{2}{|c|}{ Biofilm production $^{\mathrm{a}}$} & \multirow{2}{*}{$\begin{array}{l}\text { Resistance to } \\
\text { antibiotics }^{\mathrm{b}}\end{array}$} \\
\hline & $7^{\circ} \mathrm{C}$ & $28^{\circ} \mathrm{C}$ & $7^{\circ} \mathrm{C}$ & $28^{\circ} \mathrm{C}$ & $7^{\circ} \mathrm{C}$ & $28^{\circ} \mathrm{C}$ & \\
\hline P. putida $(\mathrm{n}=23)$ & 0 & 4 & 0 & 0 & 0 & 0 & $2^{\mathrm{c}}$ \\
\hline P. monteilii $(\mathrm{n}=16)$ & 6 & 9 & 0 & 9 & 0 & 0 & 0 \\
\hline P. fluorescens $(\mathrm{n}=13)$ & 12 & 12 & 6 & 6 & 0 & 0 & $2^{\mathrm{d}}$ \\
\hline P. mosselii $(\mathrm{n}=5)$ & 3 & 5 & 3 & 5 & 0 & 0 & 0 \\
\hline P. plecoglossicida $(\mathrm{n}=2)$ & 0 & 0 & 0 & 0 & 0 & 0 & 0 \\
\hline P. chlororaphis $(\mathrm{n}=1)$ & 0 & 1 & 0 & 1 & 0 & 0 & 0 \\
\hline P. gessardii $(\mathrm{n}=1)$ & 1 & 1 & 0 & 0 & 0 & 0 & 0 \\
\hline P. libanensis $(\mathrm{n}=1)$ & 1 & 1 & 0 & 0 & 0 & 0 & $1^{\mathrm{f}}$ \\
\hline P. vancouverensis $(\mathrm{n}=1)$ & 1 & 1 & 1 & 1 & 0 & 0 & $1^{g}$ \\
\hline Total $(n=136)$ & $57(42 \%)$ & $80(59 \%)$ & $35(26 \%)$ & $65(48 \%)$ & $0(0 \%)$ & $0(0 \%)$ & $13(9.6 \%)$ \\
\hline
\end{tabular}

${ }^{\text {a }}$ - Experiments were performed under different incubation temperatures; ${ }^{\text {b }}$ - Resistance to at least 1 of the antibiotic tested: aztreonam (ATM), cefepime (CPM), ceftazidime (CFZ), ciprofloxacin (CIP), gentamicin (GEN), imipenem (IPM), levofloxacin (LVX), meropenem (MER), piperacyllin/tazobactam (PPT) and tobramycin (TOB); ${ }^{\mathrm{c}}$ - One isolate (sample \#7) resistant to IMP and MER and one isolate (sample \#15) resistant to CFZ; ${ }^{\text {d }}$ - One isolate (sample \#16) resistant to ATM and one isolate (sample \#18) resistant to ATM and CPM; ${ }^{\text {e }}$ Six

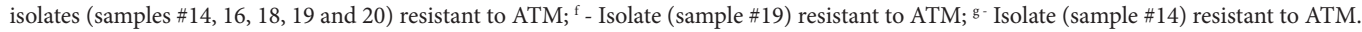

to Scatamburlo et al. (2015), the production of proteases and lipases at these temperatures demonstrates the bacterial spoilage potential under transport and processing conditions, reinforcing the need for stricter control of contamination.

Even when microorganisms are inactivated by the thermal processes used in milk processing, such as pasteurization and ultra-high temperature (UHT) treatment, proteolytic and thermolabile lipolytic enzymes remain viable and may alter the properties of milk and its derivatives, resulting in milk protein hydrolysis, bitter taste, reduced shelf life, and loss of milk thermal stability (Baur et al., 2015; Martins et al., 2015).

Qualitative evaluation of biofilm production by the isolates was also performed. The CRA method is based on increasing the production of exopolysaccharides. Other methods for biofilm detection can be used, such as microtiter plates or tube grip assays; however, other studies have reported that CRA is less expensive, faster, and more sensitive and reproducible (Hedayati et al., 2014; Amorim et al., 2018). Although biofilm detection by the microtiter plate method is the gold standard, CRA allows the quantitative assessment of biofilm formation for clinical and food-related bacteria (Hassan et al., 2011; Sheriff \& Sheena, 2016), allowing for faster detection of biofilm-producing bacteria, which is important to ensure safe and high quality milk and dairy products.

In the current study, none isolate was able to produce biofilm at $7{ }^{\circ} \mathrm{C}$ and $28^{\circ} \mathrm{C}$, however, for comparison purposes, we also performed this test at $37^{\circ} \mathrm{C}$ and 4 (2.9\%) Pseudomonas isolates, one $P$. monteilii and three P. fluorescens, were biofilm-forming. The latter species has previously been reported to be important in terms of resistance to heat treatment biofilm-forming ability.
Aswathanarayan \& Vittal (2014) used the strain P. fluorescens PSD4, isolated from a dairy processing line, as a model for biofilm production studies. They verified that this strain formed strongly adherent biofilms and had high metabolic activity at low temperatures.

According to Marchand et al. (2012), Pseudomonas spp. are prone to the production of multispecies biofilms on the walls of storage tanks, rubber lids, and raw milk cooling ducts. Because biofilms are frequently exposed to sanitizers during the cleanup of these surfaces, resistance may occur, thus adding another factor that may contribute to milk deterioration. Furthermore, other potentially pathogenic bacteria may remain protected by the pseudomonas biofilm.

Resistance to antibiotics is also a concern related to Pseudomonas sp. and may be associated with the presence of residues in milk. Little attention has been given to investigating factors that influence the presence of antibiotic residues in goat's milk and sheep's milk (Gonzalo et al., 2010; Gonzalo, 2018). The use of veterinary drugs in sheep and goats is typically intended to treat and prevent mastitis. In addition to bacterial resistance, residues of antibiotics in milk may generate other problems for the consumer, such as transient microbiota disorders and allergies (Graham et al., 2014; Quintanilla et al., 2018).

Screening tests, like Delvotest ${ }^{\circ}$, are reliable and rapidly detect antimicrobials in raw milk from different ruminants, including sheep and goats (Beltrán et al., 2015). In our study, antibiotic residues were not detected in any of the 21 raw goat's milk samples studied (Table 1). According to observations made during the acquisition of milk samples, the absence of antibiotic residues was not due to good practices or conscious care in the 
use of antibiotics, but to the fact that the production facilities were very simple, small scale, and focused on the local trade in raw goat's milk, thus not requiring the use of antibiotics to treat their goats.

P. aeruginosa is the most studied species of the genus Pseudomonas, since it is occasionally involved in outbreaks of mastitis in cows and in small ruminants, like goats (Bergonier et al., 2003; Scaccabarozzi et al., 2015). This species also commonly expresses high levels of antibiotic resistance and also multiresistance. In the current study, $P$. aeruginosa was not detected, but of the 136 isolates obtained, 13 (9.6\%) belonging to the species P. putida, $P$. fluorescens, $P$. extremorientalis, $P$. libanensis, $P$. synxantha, and $P$. vancouverensis (Table 2) showed resistance to antibiotics of one or two classes, excluding intrinsic resistance.

The low frequency of antibiotic resistant isolates may be related to the absence of antibiotic residues in the goat's milk samples, since any environment subjected to frequent contact with antibiotic residues acts as a potential hotspot for the selection, proliferation, and dissemination of resistance determinants in bacteria (Berendonk et al., 2015).

Isolates were generally resistant to aztreonam and/or cefepime or ceftazidime, with the exception of one isolate of P. putida, which was resistant to the carbapenems, imipenem and meropenem. Resistance to carbapenem antibiotics has previously been reported in P. aeruginosa (Voor In 't Holt et al., 2014; Hagemann et al., 2018) and has also been described in P. putida isolated from from clinical samples (Lee et al., 2002). The KPC (Klebsiella pneumoniae carbapenemase enzyme) phenotype of this P. putida isolate was confirmed by chromogenic agar inoculation (Chromagar ${ }^{\circledR}$ KPC). None of the isolates in the current study showed resistance to antibiotics of three or more classes and were therefore, not considered multi-resistant (Magiorakos et al., 2012).

\section{Conclusion}

The expression of proteolytic and/or lipolytic activities by the Pseudomonas sp. isolates reveals its significant spoilage potential, resulting in an even shorter shelf life of goat's raw milk. Although the samples of raw goat's milk used in this study were free of antibiotic residues, resistant isolates were found. Resistance to antibiotics in association with biofilm production may, in turn, contribute to aggregation and protection of other bacteria, including pathogens of other genera, and may result in the genetic transfer of elements associated with resistance. It is known that failure to observe good practices during milking or storage of raw goat's milk contributes to increased microbiological contamination of the product. In such cases, programs that raise awareness and provide training to producers may help ensure that the milk is of high quality, without affecting the traders' source of income.

\section{Acknowledgements}

This work was supported by the program Prociência from the Instituto Federal de Educação, Ciência e Tecnologia do Rio de Janeiro, Brazil.

\section{References}

Alegbeleye, O. O., Guimarães, J. T., Cruz, A. G., \& Sant’Ana, A. S. (2018). Hazards of a 'healthy' trend? An appraisal of the risks of raw milk consumption and the potential of novel treatment technologies to serve as alternatives to pasteurization. Trends in Food Science \& Technology, 82, 148-166. http://dx.doi.org/10.1016/j.tifs.2018.10.007.

Amorim, A. M. B., Melo, D. H., Souza, B. V., Medeiros, L. M., Mattoso, J. M. V., \& Nascimento, J. S. (2018). A reddish problem: Antibioticresistant Serratia marcescens in dairy food commercialized in Rio de Janeiro. International Food Research Journal, 25, 880-883.

Aswathanarayan, J. B., \& Vittal, R. R. (2014). Attachment and biofilm formation of Pseudomonas fluorescens PSD4 isolated from a dairy processing line. Food Science and Biotechnology, 23(6), 1903-1910. http://dx.doi.org/10.1007/s10068-014-0260-8.

Atlas, R. M. (2010). Handbook of microbiological media (4th ed.). Boca Raton, FL: CRC Press.

Baglinière, F., Tanguy, G., Jardin, J., Matéos, A., Briard, V., Rousseau, F., Robert, B., Beaucher, E., Humbert, G., Dary, A., Gaillard, J. L., Amiel, C., \& Gaucheron, F. (2012). Quantitative and qualitative variability of the caseinolytic potential of different strains of Pseudomonas fluorescens: implications for the stability of casein micelles of UHT milks during their storage. Food Chemistry, 135(4), 2593-2603. http://dx.doi.org/10.1016/j.foodchem.2012.06.099. PMid:22980847.

Baur, C., Krewinkel, M., Kranz, B., Neubeck, M., Wenning, M., Scherer, S., Stoeckel, M., Hinrichs, J., Stressler, T., \& Fishcer, L. (2015). Quantification of the proteolytic and lipolytic activity of microorganisms isolated from raw milk. International Dairy Journal, 49, 23-29. http://dx.doi.org/10.1016/j.idairyj.2015.04.005.

Beltrán, M. C., Althaus, R. L., Molina, A., Berruga, M. I., \& Molina, M. P. (2015). Analytical strategy for the detection of antibiotic residues in sheep and goat's milk. Spanish Journal of Agricultural Research, 13(1), e05-e001. http://dx.doi.org/10.5424/sjar/2015131-6522.

Beltrán, M. C., Morari-Pirlog, A., Quintanilla, P., Escriche, I., \& Molina, M. P. (2017). Influence of enrofloxacin on the coagulation time and the quality parameters of goat's milk yoghurt. International Journal of Dairy Technology, 71(1), 105-111. http://dx.doi.org/10.1111/14710307.12388.

Berendonk, T. U., Manaia, C. M., Merlin, C., Fatta-Kassinos, D., Cytryn, E., Walsh, F., Bürgmann, H., Sørum, H., Norström, M., Pons, M. N., Kreuzinger, N., Huovinen, P., Stefani, S., Schwartz, T., Kisand, V., Baquero, F., \& Martinez, J. L. (2015). Tackling antibiotic resistance: the environmental framework. Nature Reviews. Microbiology, 13(5), 310-317. http://dx.doi.org/10.1038/nrmicro3439. PMid:25817583.

Bergonier, D., de Cremoux, R., Rupp, R., Lagriffoul, G., \& Berthelot, X. (2003). Mastitis of dairy small ruminants. Veterinary Research, 34(5), 689-716. http://dx.doi.org/10.1051/vetres:2003030. PMid:14556701.

Blel, M., Guingamp, M. F., Gaillard, J. L., \& Humbert, G. (2002). Studies on the thermal sensitivity of $\gamma$-glutamyl transpeptidase measured with a modified test procedure and compared with that of alkaline phosphatase and lactoperoxidase in milk. Le Lait, 82(5), 555-566. http://dx.doi.org/10.1051/lait:2002032.

Cho, G. S., Li, B., Rostalsky, A., Fiedler, G., Rösch, N., Igbinosa, E., Kabisch, J., Bockelmann, W., Hammer, P., Huys, G., \& Franz, C. M. A. P. (2018). Diversity and antibiotic susceptibility of Acinetobacter strains from milk powder produced in Germany. Frontiers in Microbiology, 9, 536. http://dx.doi.org/10.3389/fmicb.2018.00536. PMid:29636733.

Clinical and Laboratory Standards Institute (2018). Performance standards for antimicrobial susceptibility testing: twenty-fifth Informational Supplement (CLSI Document M100-S25). Wayne, PA: CLSI. 
Corrêa, A. P. F., Daroit, D. J., Velho, R. V., \& Brandelli, A. (2011). Hydrolytic potential of a psychrotrophic Pseudomonas isolated from refrigerated raw milk. Brazilian Journal of Microbiology, 42(4), 1479-1484. http://dx.doi.org/10.1590/S1517-83822011000400034.

Decimo, M., Cabeza, M. C., Ordóñez, J. A., De Noni, I., \& Brasca, M. (2018). Volatile organic compounds associated with milk spoilage by psychrotrophic bacteria. International Journal of Dairy Technology, 71(3), 593-600. http://dx.doi.org/10.1111/1471-0307.12485.

Food and Agriculture Organization. (2018). Maximum residue limits (MRLs) and risk management recommendations (RMRs) for residues of veterinary drugs in foods - CX/MRL 2-2018. London: FAO. Retrieved from: http://www.fao.org/fao-who-codexalimentarius/codex-texts/ maximum-residue-limits/en/

Freeman, D. J., Falkiner, F. R., \& Keane, C. T. (1989). New method for detecting slime production by coagulase negative staphylococci. Journal of Clinical Pathology, 42(8), 872-847. http://dx.doi.org/10.1136/ jcp.42.8.872. PMid:2475530.

Gonzalo, C. (2018). Milk hygiene in small ruminants: A review. Spanish Journal of Agricultural Research, 15(4), 1-20. https://doi.org/10.5424/ sjar/2017154-11727

Gonzalo, C., Carriedo, J. A., García-Jimeno, M. C., Pérez-Bilbao, M., \& De la Fuente, L. F. (2010). Factors influencing variation of bulk milk antibiotic residue occurrence, somatic cell count, and total bacterial count in dairy sheep flocks. Journal of Dairy Science, 93(4), 15871595. http://dx.doi.org/10.3168/jds.2009-2838. PMid:20338436.

Graham, F., Paradis, L., Bégin, P., Paradis, J., Babin, Y., \& Des Roches, A. (2014). Risk of allergic reaction and sensitization to antibiotics in foods. Annals of Allergy, Asthma \& Immunology, 113(3), 329330. http://dx.doi.org/10.1016/j.anai.2014.06.029. PMid:25168224.

Hagemann, J. B., Pfennigwerth, N., Gatermann, S. G., von Baun, H., \& Essig, A. (2018). KPC-2 carbapenemase-producing Pseudomonas aeruginosa reaching Germany. The Journal of Antimicrobial Chemotherapy, 73(7), 1812-1814. http://dx.doi.org/10.1093/jac/ dky105. PMid:29590370.

Hantsis-Zacharov, E., \& Halpern, M. (2007). Culturable psychrotrophic bacterial communities in raw milk and their proteolytic and lipolytic traits. Applied and Environmental Microbiology, 73(22), 7162-7168. http://dx.doi.org/10.1128/AEM.00866-07. PMid:17890340.

Hassan, A., Usman, J., Kaleem, F., Omair, M., Khalid, A., \& Iqbal, M. (2011). Evaluation of different detection methods of biofilm formation in the clinical isolates. The Brazilian Journal of Infectious Diseases, 15(4), 305-311. http://dx.doi.org/10.1016/S1413-8670(11)70197-0. PMid:21860999.

Hedayati, S., Eftekhar, F., \& Hosseini, S. M. (2014). Biofilm formation by bacteria isolated from intravenous catheters. Journal of Medical Bacteriology, 3, 26-31.

Hodgkinson, A. J., Wallace, O. A. M., Boggs, I., Broadhurst, M., \& Prosser, C. G. (2017). Gastric digestion of cow and goat milk: Impact of infant and young child in vitro digestion conditions. Food Chemistry, 245, 275-281. http://dx.doi.org/10.1016/j.foodchem.2017.10.028. PMid:29287371.

International Organization for Standardization (2004). ISO 21528-2: Microbiology of food and animal feeding stuffs - Horizontal method for the detection and enumeration of Enterobacteriaceae - Part 2: Colony count method. Geneva, Switzerland: ISO.

International Organization for Standardization (2013). ISO 4833-2:2013: Microbiology of food and animal feeding stuffs. Horizontal method for the enumeration of microorganisms. Colony-count technique at $30{ }^{\circ} \mathrm{C}$ by the surface plating technique. Geneva, Switzerland: ISO.
Lai, C. Y., Fatimah, A. B., Mahyudin, N. A., Saari, N., \& Zaman, M. Z. (2016). Physico-chemical and microbiological qualities of locally produced raw goat milk. International Food Research Journal, 23, 739-750.

Lee, K., Lim, J. B., Yum, J. H., Yong, D., Chong, Y., Kim, J. M., \& Livermore, D. M. (2002). bla-VIM2 cassette-containing novel integrons in metallo- $\beta$-lactamase-producing Pseudomonas aeruginosa and Pseudomonas putida isolates disseminated in a Korean hospital. Antimicrobial Agents and Chemotherapy, 46(4), 1053-1058. http:// dx.doi.org/10.1128/AAC.46.4.1053-1058.2002. PMid:11897589.

Lingathurai, S., Vellathurai, P., Vendan, S. E., \& Prem, A. A. (2009). A Comparative study on the microbiological and chemical composition of cow milk from different locations in Madurai, Tamil Nadu. Indian Journal of Science and Technology, 2, 51-54.

Magiorakos, A. P., Srinivasan, A., Carey, R. B., Carmeli, Y., Falagas, M. E., Giske, C. G., Harbarth, S., Hindler, J. F., Kahlmeter, G., OlssonLiljequist, B., Paterson, D. L., Rice, L. B., Stelling, J., Struelens, M. J., Vatopoulos, A., Weber, J. T., \& Monnet, D. L. (2012). Multidrugresistant, extensively drug-resistant and pandrug-resistant bacteria: an international expert proposal for interim standard definitions for acquired resistance. Clinical Microbiology and Infection, 18(3), 268-281. http://dx.doi.org/10.1111/j.1469-0691.2011.03570.x. PMid:21793988.

Marchand, S., De Block, J., De Jonghe, V., Coorevits, A., Heyndrickx, M., \& Herman, L. (2012). Biofilm formation in milk production and processing environments; influence on milk quality and safety. Comprehensive Reviews in Food Science and Food Safety, 11(2), 133147. http://dx.doi.org/10.1111/j.1541-4337.2011.00183.x.

Martins, M. L., Pinto, U. M., Riedel, K., \& Vanetti, M. C. D. (2015). Milk-deteriorating exoenzymes from Pseudomonas fluorescens 041 isolated from refrigerated raw milk. Brazilian Journal of Microbiology, 46(1), 207-217. http://dx.doi.org/10.1590/S1517-838246120130859. PMid:26221110.

Mituniewicz-Małek, A., Zielińska, D., \& Ziarno, M. (2019). Probiotic monocultures in fermented goat milk beverages - sensory quality of final product. International Journal of Dairy Technology, 72(2), 240-247. http://dx.doi.org/10.1111/1471-0307.12576.

Oliver, S. P., Boor, K. J., Murphy, S. C., \& Murinda, S. E. (2009). Food safety hazards associated with consumption of raw milk. Foodborne Pathogens and Disease, 6(7), 793-806. http://dx.doi.org/10.1089/ fpd.2009.0302. PMid:19737059.

Quintanilla, P., Beltrán, M. C., Peris, B., Rodríguez, M., \& Molina, M. P. (2018). Antibiotic residues in milk and cheeses after the off-label use of macrolides in dairy goats. Small Ruminant Research, 167, 55-60. http://dx.doi.org/10.1016/j.smallrumres.2018.08.008.

Ranadheera, C. S., Evans, C. A., Baines, S. K., Cruz, A. G., Esmerino, E. A., Freitas, M. Q., Pimentel, T. C., Wittwer, A. E., Naumovski, N., Graça, J. S., Sant’Ana, A. S., Ajlouni, S., \& Vasiljevic, T. (2019). Probiotics in Goat Milk Products: Delivery Capacity and Ability to Improve Sensory Attributes. Comprehensive Reviews in Food Science and Food Safety, 18(4), 867-882. http://dx.doi.org/10.1111/15414337.12447.

Ribeiro Júnior, J. C., Oliveira, A. M., Silva, F. D. G., Tamanini, R., Oliveira, A. L. M., \& Beloti, V. (2018a). The main spoilage-related psychrotrophic bacteria in refrigerated raw milk. Journal of Dairy Science, 101(1), 75-83. http://dx.doi.org/10.3168/jds.2017-13069. PMid:29102138.

Ribeiro Júnior, J. C., Teider, P. I. Jr, Oliveira, A. L., Rios, E. A., Tamanini, R., \& Beloti, V. (2018b). Proteolytic and lipolytic potential of Pseudomonas spp. from goat and bovine raw milk. Pesquisa Veterinária Brasileira, 38(8), 1577-1583. http://dx.doi.org/10.1590/1678-5150-pvb-5645. 
Sato, J., Ohno, H., \& Matsui, C. (2014). Applicability of the ISO Enterobacteriaceae Test for determining the suitability of pasteurized milk for shipment. Japanese Journal of Food Microbiology, 31(2), 86-92. http://dx.doi.org/10.5803/jsfm.31.86.

Scaccabarozzi, L., Leoni, L., Ballarini, A., Barberio, A., Locatelli, C., Casula, A., Bronzo, V., Pisoni, G., Jousson, O., Morandi, S., Rapetti, L., García-Fernández, A., \& Moroni, P. (2015). Pseudomonas aeruginosa in dairy goats: genotypic and phenotypic comparison of intramammary and environmental isolates. PLoS One, 10(11), e0142973. http://dx.doi.org/10.1371/journal.pone.0142973. PMid:26606430.

Scatamburlo, T. M., Yamazi, A. K., Cavicchioli, V. Q., Pieri, F. A., \& Nero, L. A. (2015). Spoilage potential of Pseudomonas species isolated from goat milk. Journal of Dairy Science, 98(2), 759-764. http://dx.doi. org/10.3168/jds.2014-8747. PMid:25497792.

Sheriff, R., \& Sheena, A. (2016). Assessment of biofilm production in clinically significant isolates of Staphylococcus epidermidis and comparison of qualitative and quantitative methods of biofilm production in a tertiary care hospital. International Journal of Scientific Study, 4, 41-46. http://dx.doi.org/10.17354/ijss/2016/482.

Voor In 't Holt, A. F., Severin, J. A., Lesaffre, E. M., \& Vos, M. C. (2014). A systematic review and meta-analyses show that carbapenem use and medical devices are the leading risk factors for carbapenem-resistant Pseudomonas aeruginosa. Antimicrobial Agents and Chemotherapy, 58(5), 2626-2637. http://dx.doi.org/10.1128/AAC.01758-13. PMid:24550343. 